\title{
Languages of Mourning: Between Page and (Modern) Stage
}

\author{
Justyna Biernat \\ Jagiellonian University
}

\begin{abstract}
The aim of this essay is to provide an analysis of the Euripides' "Phoenician Women" in terms of mourning. The author intends to set a parallel between the ancient tragedy and its modern adaptation staged by one of the most prominent Polish directors Krzysztof Warlikowski. In the essay, the author will discuss how suffering is depicted in the ancient drama and what changes of mourning motif are introduced into its modern performance. The author will examine the literary as well as the (modern) theatrical topos of grief by analyzing the poetics of tragedy (dramatic structure, metaphors of death, dramatis personae, funeral vocabularium, function of laments) and the poetics of performance (stage design, costumes and props, funerary symbolism, acting, directing solutions). The purpose of the paper is to argue against the insignificance of Euripides' drama and the marginalization of Warlikowski's "Phoenician Women." Finally, the author will attempt to indicate the mourning motif as one of the essential and attractive for the ancient tragic plot and the modern performance as well.
\end{abstract}

Keywords: Euripides, Krzysztof Warlikowski, Greek tragedy, mourning

\section{Introduction}

In one of the central scenes of the Euripides' "Phoenician Women," the future king of Thebes Creon enters to expose and mourn the death of his younger son. He begins his lament with the characteristic, mourning question: Ah, ah, what shall I do? Shall I weep and groan for myself or my city ${ }^{1}$ and continues his weeping for the heroic self-sacrifice of Menoeceus and the ongoing war on the tainted Theban land. Meanwhile in the Warlikowski's performance, we can see the solitude of the boy's suicidal act accompanied by the Choral song and cry. After the symbolic Menoeceus' fall, Creon is striding the stage, slowly raises his son, and holding him in his arms, walks away into darkness. There is only silence.

In this essay, the author intends to analyse the differences of the mourning depictions between ancient page and modern stage. The author will examine the literary and theatrical topos of calamity by studying the poetics and structure of drama as well as the aesthetics and arrangement of the dramatic production. The purpose of the essay is to describe the main components of drama (narration, symbols, and metaphors) considering mourning and its significance to the dramatic on-stage tension. The author will analyze dramatic figures of calamity, dramaturgical phase of grief in the construction, sources of expression in drama and on stage as well as the vocabulary of loss. The author will also take a challenge to argue against insignificance of the Euripides' drama and the marginalization of the Warlikowski's "Phoenician Women." Finally, the author will attempt to indicate how fruitful, attractive, and clever modern dialog with former poetics can be.

Justyna Biernat, Ph.D., Polish Department, Jagiellonian University, Poland; main research fields: Drama and Theatre Studies, Ancient Greek Tragedy and its Reception on Modern Stage, Modern Hebrew Drama, and Theatre and Holocaust. Email: justyna.biernatowa@gmail.com. 
The author will begin the analysis by the trial of drama description with emphasis on the selected scenes. Having in mind the complexity of problems associated with the authenticity of particular scenes, the author withdraw from reflecting on the extensive interpolations since the interest is to look at the Euripides' "Phoenician Women" as a ready-made material or "a script" for the modern director who searches in antiquity for his own artistic expression. After that, the author will provide the interpretation of the production.

\section{Euripides’ Drama}

Produced probably in 410-409 B.C., Euripides' "Phoenician Women" used to be estimated by scholars as an overstuffed drama with inconsistent and overcrowded plot. ${ }^{2}$ In fact,

Its open form, as noted by Mastronarde, tends in the opposite direction, diminishing concentration and hierarchy in various ways. Event becomes as prominent as, or more prominent than, action. The number of figures involved in the action is increased and their separate influence on the course of event reduced. The rhythm of complication and resolution is varied and multiplied. ${ }^{3}$ (Donald Mastronarde 2010, 64)

The "Phoenician Women" combines seemingly irrelevant and episodic scenes, which seems to be a sign of modern dramatic structure. The autonomous sections tend to question the dynamic development of the action and to break the tradition of the cause and effect plot. However, the new idea of "dramatic events" Euripides to make the myth, mourning, and memory - the overriding subject of the drama. It also divides the plot into particular stories of the individual dramatis personae (characters) in order to differentiate the picture and problem of suffering.

In his drama, Euripides freely transforms the myth of the Labdacids. These shifts deepen the mourner's image and intensify the horror of the Theban war. Here is a fratricidal struggle between Polyneices and Eteocles done in front of their mother Jocasta and young sister Antigone, while old, blinded Oedipus stays locked in the palace due to the unlawful commands of his sons. The drama is opened with a long speech of Jocasta who, by the story of the Labdacids, draws the audience's attention to the tragedy's characters. Significantly, characters are presented on the background of the whole history of the city, woven into the web of relationships within family (genos). The opening monologue allows us to understand the present moment of the fraternal quarrel and the factors that shape it.

There are two basic compositional techniques which help to asses that knowledge. In the first, the audience recognizes the past gradually, from distance... Meanwhile the second moves the process of uncovering the past into the interior world of drama and makes the object of knowledge one of the characters who are deeply associated with the past events... This dramatic solution exacerbates the expressiveness of the process as the audience loses the comfort of distance related to "extraneous" and becomes the witness of the character's way to the truth. ${ }^{5}$ (Stoff Andrzej 1995, 121)

Euripides uses the conventional method of introducing the audience to the past - the exposition - which aims to make the past significant component of the present. The exposition also explores the structure, tension, and wretched regularity of the history. The monologue of Jocasta is framed by invocations directed to heaven. The call to Helios seems to be an essential part of the poetics of mourners who in their traumatic experience always invoke the sun to become a witness of their disaster, while the apostrophe to Zeus is an appeal to rescue the estranged sons and Thebes. The old Jocasta in mourning with her hair cut short and in black robes is a figure of a suffering mother, who has to weep over calamity of her homeland, her relatives, and her own life and deeds. She seems to be a messenger who precisely describes the events which she witnesses, and as a result she becomes a carrier of their memory and trauma. She also may be seen as a mirror image of Oedipus who 
will take her place at the end of the play and will continue the story of the familial pollution (miasma). Jocasta's monologue has an informative rather than lamenting character.

After the opening monologue, the old servant and Antigone enter to see at the girl's request the approaching Argive army. The scene is a kind of descriptio loci (description of setting) - the conversation expands the action space and announces the forthcoming fight.

Apart from characterizing the initial state of Antigone (from which she will be forced to grow by later events) and adumbrating the justice of Polynices' cause, the teichoscopia (literally looking from the walls. It is a narrative strategy in Greek literature) advances the exposition by evoking the wider vista of the beleaguered Theban landscape, the strength and fearsomeness (and partly ferocity) of the attacking army and its leaders, and the fear of the potential captives within the city. ${ }^{6}$ (Donald Mastronarde 1994)

Among many soldiers, described by the servant, Antigone spots her brother and expresses her longing for him with the use of metaphorical language: Would I speed through the sky, swift as a cloud before the wind [165] towards my own dear brother, and throw my arms about my darling's neck, so long, poor boy!

"The Antigone's perspective on the action is characterized by her literal as well figurative distance from it, and by her ability to find order and brightness in the scene laid out before her" (Foley Helen 1985). ${ }^{8}$ She cannot have the moral seriousness of the situation as she is young and not aware of family pollution. However, the plot will present the dynamic process of her increasing awareness and active immersion in events.

The Parodos is a self-presentation of the Chorus which consists of Phoenician maidens sent by Agenoridae of Tyre to be hierodouloi (temple-slaves) at Delphi. As Mastronarde mentioned (1994), "Euripides likes to concentrate the action and the strongest emotional stresses and reactions in the actors, and accordingly favours in general powerless choruses, sympathetic but not too intimately tied to the fate of the protagonists" (Donald Mastronarde 2010). ${ }^{9}$

The first Episode seems to be an anticipation of the fight and consists of two large sections. "In the second, there is a famous agon logon (contest of arguments) of Eteocles and Polynices with Jocasta as arbitrator. In the first, however, Polynices shares the stage with his mother and his dilemma is given a full and sympathetic exposure through an emotional aria of reunion and grief" (Donald Mastronarde 1994). ${ }^{10} \mathrm{He}$ is undoubtedly a positive exile figure, who confesses his grief and attachment to his homeland and family in the metaphor of streams of tears. The mourning vocabulary (vocabularium) gradually shivers the presented word and announces disaster. The increasing tension of the plot can be seen in the Jocasta's expression that "I am miserable in many ways" 11 after her unsuccessful attempts to reconcile her sons.

Before the battle comes, the prophet Tiresias enters to inform Creon that Thebes will not survive the attack of Polynices and his allies unless Creon's younger son, Menoeceus, the last of the pureborn sown men of Thebes, is sacrificed to appease Ares. Even though Creon does not accept the prophecy and orders his son to leave the city, Menoeceus decides to sacrifice himself. "The isolation of this heroism in a naive youth, its location in a symbolic action which has no correspondence in contemporary political life, and the final conclusion of the war with the Argives retrospectively cast a bitter light on Menoeceus' act" (Donald Mastronarde 1994). ${ }^{12}$ The thematic connection and function of the Menoeceus scene seem to be sufficient to rebut the orthodox criticism that it is an index of episodic composition without necessary relation to the remainder of the play. The heroism of Menoeceus is expressed by the Creon's short lament that probably enters holding his son in his arms. Creon is a restrained mourner who, except for expression of his misfortune in few mourning phrases of weeping (moan, weep, unfortunate, or wretched), intends to announce the death of his son 
and asks Jocasta for a proper burial. The scene evokes the shadow of fear and death in the metaphor of a cloud around the city as if it went through Acheront. Perhaps Creon's self-restraint is an equivalent of strength and relentlessness while the death of his son is a justification of his future rules. He himself will listen to the Messenger's speech about the fratricidal death of Polynices and Eteocles and their mother's suicidal act.

The Messenger's rhesis (speech) is followed immediately by the entrance of Antigone accompanying three corpses. This is the emotional climax of the play and the most significant depiction of a mourner figure. The Antigone's monologue shifts among three topics: self-presentation as a mourner, announcement and interpretation of the disaster, and the aporetic rhetoric of grief. The Antigone's words create a metaphor of Bacchic frenzy with the desertion of the limits of decency and rationality. They are the signal of the rupture of the previous standards of appropriateness. It seems to be a moment of the exposure of madness and suppressed despair-Antigone is hitherto only an observer of events, always in someone's company. The resignation of the youthful ornaments is a symbol of separation from the position of an obedient, silent witness and adoption of a role of a leader of the dead. Antigone is an exceptional and strong figure of violent mourning as she is a defender of her brother's burial and her father's disability as well as a rebel against her marriage with Haemon. While her lament is an important component of the dramatic structure - it seems to be a turning point in the tragedy as it closes the plot of fraternal fight and opens the Oedipus' exile, the new order in which she becomes the main character. She calls Oedipus out who has been mentioned repeatedly during the play as present in the house and affected by events. Oedipus receives the news in "a lyric reworking of the material already presented by messenger." 13 The climax is a beautiful passage of striking style and imagery presenting in pathetic terms the suicide of Jocasta and an act of solidarity with her unfortunate sons. The end of the play is a unity of frenzy Antigone in mourning and the old, blind Oedipus who as a shadow (skia) emerges from the palace and will follow his daughter in common exile. He has been living on the border between the living and the dead-away from the everyday life of the city and his relatives, like a dead, doomed to wandering on the earth, having no place among the living and no admission to the dead in Hades. He is replacing Jocasta who takes and leaves Antigone alone in the battlefield. However, this time, Antigone herself will testify to the Labdacids' disaster of which the visible sign Oedipus' blindness will become.

\section{Warlikowski’s Play}

Let me now turn to Krzysztof Warlikowski, who is one of the most significant theatre directors on modern European stage, in order to set the parallel between the tragedy and its contemporary performance. "The Phoenician Women" was directed by him in 1998 in Municipial Theater (Beer Sheva, Israel). It was only one year after his staging of Sophoclean "Electra" in Warsaw before his famous and scandalous "Bacchae" (Warsaw, 2001). Greek tragedies have been always an essential part of Warlikowski's artistic activity, though nowadays he prefers to combine different texts (drama, prose, fiction) and forms (dramatic theatre, opera, cabaret, media on stage, concerts) rather than to follow one particular writer or dramatist. In his theatre, however, Warlikowski has continually addressed the problem of memory and post memory, religion, the history of holocaust, trauma, and sexuality no matter if he works on Greek tragedies, Shakespearian or Hebrew drama, theatre of the Absurd, or finally postdramatic or in-yer-face theatre ${ }^{14}$.

"The Phoenician Women" belongs to the first independent plays directed by Warlikowski after his co-operation as an assistant with Krystian Lupa, Peter Brook, Ingmar Bergman, and Gorgio Strehler. The performance used to be marginalized. Perhaps the reason is the initial imperfection of Warlikowski's directing 
or simply inaccessibility of performance caused by Hebrew language. "The Phoenician Women" is not a typical or representative Warlikowski's performance, however, they surely mark out his way to the artistic maturity and create his metaphorical theatre language. What is more, they are a testimony of his clever dialog not only with ancient Greek culture but also with modern Hebrew history.

The stage sinks in darkness and sitting Jocasta in the black robes becomes the part of that darkness. Her opening monologue is a dramatic confession of the old mourner who makes us witnesses of her grief and her way to the terrifying truth of Theban crimes. The invocation directed to Helios is juxtaposed with dark and empty space - the symbolic sorrow and solitude. It seems that Jocasta has been just realizing what happened to her family (genos), but at the same time she does not feel guilt. She is simply not able to understand the pain she bears. A narrow beam of light, falling on her head, exposes her grey hair and tired, wrinkled face which she covers with her hands. Her gestures and body position express the painful awareness of the past and its consequences. She speaks a subdued and calm voice but the words seem to be very difficult for her. Perhaps she suspects that her attempts to reconcile her sons will be in vain or perhaps she already knows that there will be only one way - a suicide. Her position can be accurately expressed with the passages from Dostoyevsky's "A Writer's Diary:"

Conscious implies suffering, but I do not wish to suffer, since why should I consent to suffering? Nature, though the medium of my consciousness, proclaims to me some sort of harmony of the whole. Human consciousness has produced religions out of this message ... abase myself, accept suffering because of the harmony of the whole, and consent to live... And why should I bother about its preservation after I no longer exist - that is a question... But my consciousness is not harmony, but, on the contrary precisely disharmony, because with it I am unhappy. ${ }^{15}$ (Fyodor Dostoyevsky 1994)

She disappears in darkness and the empty, gloomy space is filled with the brightness.

There is an exceptional teichoscopia scene where Antigone and Menoeceus with admiration and little fear watch the impending Argive army. They are completely unaware of the forthcoming disaster, while the spectrum of the bright, warm colours, and smiles underlines their innocence and carelessness. The embarrassing kiss - a sign of their chastity belongs to their youthful thoughts and creates the tension between them and the reality of Jocasta's mourning and war in which they will be soon involved. Meanwhile, they spend their time together, perhaps on the meadow where Antigone has got the flowers and accidentally noticed strange sounds and sight which interrupt their dance. This significant shift brings new quality of Antigone's and Menoeceus' personal, intimate word. The scene is a surprising parallel to the opening, mournful monologue. Jocasta pulls the audience into her painful story meanwhile two young friends are caught having a good time together in face of war.

After the teichoscopia scene, the Chorus enters the stage and the symbolic gesture of putting the paper ship on the floor describes the voyage. The female singer in her exotic clothes accompanied by instrumental music will be a witness of all events and her melodic voice will become a background of the main plot. The music is a frame of the performance and makes a rhythm by its tone, speed, and strength. In the climatic moments of the plot, she will start screaming as an emotional and dynamic narrator of the story which is enacted in front of the audience.

The singer will be the only witness of Menoceues' suicide after the prophecy of old, friendly Tirezias who hugs him and Antigone. It seems that the prophet gives his white wreath, a symbol of glory to the boy sloppily as if he wanted to get rid of it after a tiring, walking route. However, for Menoceues, that wrath is a commitment and responsibility for the entire city and a need to satisfy the world of adults. He will stand in the 
middle of the stage. A narrow beam of light will expose his frail figure, laden legs, and shaking knees. His face will be shining with excitement, but step by step he will be more terrified. Before the fall, he will stop and swing with his arms wide open as if he were on the precipice and were scared of height. Finally, he will jump from the tower and his father will raise him from the ground. Creon will not lament his son but put him on the side of the stage. This significant silence is a fulfilment of the solitary Menoceues' act that could not have known about the order of the rituals. As a result, his self-sacrifice is deprived of a prayer and community, deprived of a joyful, sacred cry, and accompanied by scream of the Chorus.

Jocasta will also commit suicide and brothers will perish during the fratricidal duel. They will stand in front of each other on the sand like eastern warriors in long, dark skirts. Significantly, there will be no symbols of death or violent, no blood stains or weapons. The fight will resemble the bantering and the attack will fluctuate into the strong hug. All with the music are transformed into scream.

\section{Conclusions}

"The Phoenician Women" is a story of the city as well as a family trapped by the war. This war is illustrated not only as an act of violence, but also a consequence of longing and departure. The fragmentary narration of the drama seems to be an intended Euripidean strategy of a depiction of individual suffering and mourning as personal experience. Warlikowski exposes the war as a lack of intimacy and makes the seemingly inconsistent drama coherent with the use of theatrical tools. The whole performance emanates beauty and harmony as well as simplicity of a stage design. It evidently avoids asymmetry and disharmony, and defends itself against the symbolic of slaughter, violence, and mourning. The performance gives a sort of pleasure and calm, and the ugliness of breaking up and devastation is transformed into an object of beauty. We can ask: "Can the beautiful be sad? Is beauty inseparable from the ephemeral and hence from mourning? Or else is the beautiful object the one that tirelessly returns following destruction and wars in order to bear witness that there is survival after death, that immortality is possible" (Julia Kristeva 1992). ${ }^{16}$ The idea of beauty as an impulse to recover and recreate the lost world is related to the performance and the history of suffering Theban or Israeli land. The Warlikowski's "Phoenician Women" seems to be a trial of taming the traumatic experience and the story of disaster. It brings the hope for reconciliation and forgiveness. Finally, it suggests that mourning can be recovered.

\section{Notes}

1. Ah, ah, what shall I do? Shall I weep and groan for myself or my city (V. 1310-11). All translations: Euripides, Phoenissae. Ed., Donald J. Mastronarde. Cambridge: Cambridge University Press, 1994.

2. Foley, Helen, P., Ritual Irony: Poetry and Sacrifice in Euripides. Oxford: Oxford University Press, 1985.

3. Mastronarde, Donald, J., The Art of Euripides. Dramatic Technique and Social Context. Cambridge: Cambridge University Press, 2010.

4. Problemy teorii dramatu i teatru. Ed. Janusz Degler. Wrocław: Wydawnictwo Uniwersytetu Wrocławskiego, 1988.

5. Stoff, Andrzej, Drama and Time. Trans., Justyna Biernat, Toruń: Uniwersytet Mikołaja Kopernika, 1995, 121.

6. Euripides, Phoenissae. Ed., Donald J. Mastronarde. Cambridge: Cambridge University Press, 1994.

7. Would I could speed through the sky, swift as a cloud before the wind [165] towards my own dear brother, and throw my arms about my darling's neck, so long, poor boy!

8. Foley, Helen, P., Ritual Irony: Poetry and Sacrifice in Euripides. Oxford: Oxford University Press, 1985.

9. Mastronarde, Donald, J., The Art of Euripides. Dramatic Technique and Social Context. Cambridge: Cambridge University Press, 2010.

10. Euripides, Phoenissae. Ed., Donald J. Mastronarde. Cambridge: Cambridge University Press, 1994. 
11. I am miserable in many ways (V. 619)

12. Euripides, Phoenissae. Ed., Donald J. Mastronarde. Cambridge: Cambridge University Press, 1994.

13. Euripides, Phoenissae. Ed., Donald J. Mastronarde. Cambridge: Cambridge University Press, 1994.

14. In-yer-face theatre describes drama of Sarah Kane, Mark Ravenhill, Anthony Neilson. It is a term defined by critic Aleks Sierz who described dramas written in Great Britain in the 1990s.

15. Dostoyevsky, Fyodor, A Writer's Diary. Northwestern USA: University Press, 1994.

16. Kristeva, Julia, Black Sun: Depression and Melancholia. Columbia: Columbia University Press, 1992.

\section{Works Cited}

Dostoyevsky, Fyodor. A Writer's Diary. Northwestern USA: University Press, 1994.

Euripides. Phoenissae. Ed., Donald Mastronarde. Cambridge: Cambridge University Press, 1994.

Foley, Helen. Ritual Irony: Poetry and Sacrifice in Euripides. Oxford: Oxford University Press, 1985.

Kristeva Julia. Black Sun: Depression and Melancholia. Columbia: Columbia University Press, 1992.

Problems of Theatre and Drama Theories. Ed., Janusz Degler. Wrocław: Wydawnictwo Uniwersytetu Wrocławskiego, 1988.

Stoff, Andrzej. Drama and Time. Trans., Justyna Biernat. Toruń: Uniwersytet Mikołaja Kopernika, 1995. 121. 